\title{
I Refugee: Memories
}

\section{Yo refugiado: Memorias}

\author{
Alicia Garza
}

Since the day I was born I knew death was coming.

Desde el día que nací sabia que la muerte venía.

In a way that children should not acknowledge their end,

De una manera que niños no deberían reconocer su fin,

with the exception of those plagued from a young age

con la excepción de aquellos plagados desde una edad temprana

by biology's cruel incantations.

por los conjuros crueles de la biología.

No, mine was death born out of life's incoherence.

No, la muerte mía nació de las incoherencias de la vida.

It is true that often the dead are more alive than the living, Es verdad que muchas veces los muertos son más vivos que los vivos,

and the living are more dead than living. $y$ los vivos son más muertos que vivos.

And in this way I felt the threat and knew of the ills before I lived the joys.

$Y$ de esta manera sentí la amenaza y conocí los males antes de vivir el bien.

As often humans try to distinguish between the good and bad memories, Los humanos suelen hacer el intento de distinguir entre las lindas y malas memorias, 
I too tried but never achieved an organized account of memorable experiences también intenté pero no logré un compendio organizado de experiencias memorables

because it was perilous to look back even at the happy ones. porque era arriesgado recordar hasta las felices.

So in this way, I can report that I was dead from the moment I breathed life Así que, de esta manera puedo afirmar que yo parecía muerto desde el momento que cobré vida and it has been my objective $y$ ha sido mi objetivo

to find life and sanctity everywhere it wasn't and everywhere it could be. encontrar vida y santidad en todas partes que no se encuentra y en todas partes que podría estar.

This frantic search proved useless, Esta búsqueda frenética resultó inútil,

and here I am starting from the beginning and giving life to all that was lost. y acá estoy comenzando desde el inicio y resucitando todo lo perdido. 